\title{
Human autoantibodies: probes for nucleolus structure and function
}

\author{
Georg Reimer ${ }^{1}$, Ivan Raška ${ }^{2}$, Eng M. Tan ${ }^{3}$, and Ulrich Scheer ${ }^{4}$ \\ ${ }^{1}$ Department of Dermatology, University of Erlangen-Nürnberg, D-8520 Erlangen, Federal Republic of Germany \\ ${ }^{2}$ Institute of Experimental Medicine, Czechoslovak Academy of Sciences, Prague, CSSR \\ ${ }^{3}$ W.M. Keck Foundation Autoimmune Disease Center, Scripps Clinic and Research Foundation, La Jolla, \\ California 92037, USA \\ ${ }^{4}$ Institute of Zoology I, University of Würzburg, D-8700 Würzburg, Federal Republic of Germany
}

Autoantibodies against cellular components are spontaneously produced by patients with systemic autoimmune disease such as systemic lupus erythematosus (SLE), dermatomyositis, Sjögren's syndrome and systemic sclerosis (scleroderma). Such cellular autoantigens include DNA, RNA, histones and a variety of nuclear, nucleolar and cytoplasmic proteins and RNA-protein complexes (reviewed by Kalden and Feltkamp 1982; Tan 1982; Seelig 1983). A characteristic of these autoantigens is that they are generally not tissue and species-specific but represent evolutionary conserved integral components of cells from a wide variety of different species. The molecular identity of several nonhistone protein autoantigens has recently been revealed. For example, certain myositis-related autoantigens were shown to be histidyl-tRNA and threonyl-tRNA synthetase, respectively (Mathews and Bernstein 1983; Mathews et al. 1984). Scleroderma-associated nuclear/nucleolar autoantigen Scl-70 (Douvas et al. 1979) was recently identified as DNA topoisomerase I (Guldner et al. 1986; Maul et al. 1986; Shero et al. 1986). In two previous publications certain autoantibodies from SLE sera were reported to recognize two acidic phosphoproteins of the large ribosomal subunit, designated P1/P2 (L40/L41) in rat, which function in the elongation step of protein synthesis (Francoeur et al. 1985; Elkon et al. 1985).

Antibodies from autoimmune patients have also successfully been used as reagents in answering basic questions concerning the molecular biology of the cell. For example, autoantibodies against $\mathrm{U} 1$ and U2 small nuclear ribonucleoproteins were shown to inhibit splicing of heterogeneous nuclear

Offprint request to: $\mathrm{U}$. Scheer at the above address
RNA, implicating an important role of these ribonucleoproteins in the processing of precursor mRNA (Padgett et al. 1983; Black et al. 1985; also reviewed by Maniatis and Reed 1987). SS-B/La, a small nuclear ribonucleoprotein particle, as identified by autoimmune sera, appears to be involved in the transport and/or maturation of RNA, mostly RNA polymerase III transcripts (Steitz et al. 1983). More recent data suggest that the SS$\mathrm{B} / \mathrm{La}$ particle is either a termination factor for RNA polymerase III or is involved in posttermination processing events (Stefano 1984).

Antibodies reactive with nucleolar components are part of the spectrum of autoantibodies present in autoimmune sera, particularly from patients with scleroderma, as has been reported by many investigators (Ritchie 1970; Pinnas et al. 1973; Tan et al. 1980; Bernstein et al. 1983; Reimer et al. 1983). Previously, antinucleolar autoantibodies were used in immunofluorescence microscopy by several investigators to gain insight into the structural organization of the nucleolus (Ritchie 1969; Ringertz et al. 1973; Hernandez-Verdun et al. 1979). However, only very recently have antinucleolar autoantibodies been used more systematically to identify and localize new proteins within the nucleolus and answer basic questions concerning mechanisms associated with ribosome biogenesis (see below).

The structure of the nucleolus is closely associated with its sole function, i.e. to generate ribosomes in eukaryotic cells (reviewed by Busch and Smetana 1970; Hadjiolov 1985). Biochemical studies have shown that ribosome biogenesis in the nucleolus takes place in a well-defined maturation process. In mammalian cells, ribosomal genes are transcribed into $45 \mathrm{~S}$ pre-rRNA, which is then 
methylated and assembled with specific ribosomal and nonribosomal proteins to form the so-called preribosomes. The $45 \mathrm{~S}$ precursor RNA is then sequentially cleaved to form $28 \mathrm{~S}, 18 \mathrm{~S}$ and 5.8S RNA. The formation of mature ribosomes is a complex process involving many intermediate steps of which there is little information availabe especially on the protein level. Various species of preribosomal particles have been isolated by biochemical fractionation of isolated nucleoli and shown to contain ribosomal proteins and also other proteins that are absent from mature cytoplasmic ribosomes (reviewed by Busch 1984; Hadjiolov 1985).

By electron microscopy, at least three different nucleolar components can be recognized. These are the granular component, the dense fibrillar component and the fibrillar centers (Busch and Smetana 1970; Goessens 1984; Hadjiolov 1985). Recently, different nucleolar proteins have been assigned to the various nucleolar structures by immunocytochemical techniques using experimentally raised antibodies from immunized animals. Using a specific rabbit antiserum, RNA polymerase I has been localized by light and electron microscopic immunocytochemistry in the fibrillar centers of interphase nucleoli and the nucleolar organizing regions of metaphase chromosomes (Scheer and Rose 1984). Using monoclonal antibodies, Kistler et al. (1984) found two nucleolar proteins of mol wt $\left(\mathrm{M}_{\mathrm{r}}\right)$ 110000 and 94000 associated with the fibrillar component, a third $\mathrm{M}_{\mathrm{r}} 40000$ protein was accumulated in the periphery of nucleoli and in the cytoplasm. The granular component was shown to contain a specific ribosomal protein (S1) of the small ribosomal subunit (Hügle et al. 1985a) and a $\mathrm{M}_{\mathrm{r}} 40000$ nucleolar protein (ribocharin) associated with precursor particles of the large ribosomal subunit in amphibian cells (Hügle et al. 1985b). A $M_{r} 180000$ structural nucleolar protein identified by a monoclonal antibody was shown to contribute to the dense fibrillar component (SchmidtZachmann et al. 1984). A proteinaceous filament network insoluble in low and high salt buffers as well as non-denaturing detergents and containing a protein of $M_{r} 145000$ as a major if not exclusive constituent has been detected in the amplified nucleoli of Xenopus laevis oocytes (Franke et al. 1981). As shown by light and electron microscopic immunocytochemistry, this nucleolar karyoskeleton structure is predominantly enriched in the periphery of amplified nucleoli and occurs also in nucleoli of somatic Xenopus cells (Krohne et al. 1982; Benavente et al. 1984). It has been suggested that these filament structures provide structural support for the attachment of preribosomal parti- cles and may be involved in the maturation process of ribosomal precursor material (Franke et al. 1981 ; Benavente et al. 1984). Nucleolar nonribosomal phosphoprotein B23 $\left(\mathrm{M}_{\mathrm{r}} 37000\right)$, believed to be associated with preribosomes, was localized by monoclonal antibodies in the granular component of Novikoff hepatoma ascites cells (Spector et al. 1984) and chick muscle cells (Morris et al. 1985). Recently, a nucleolar protein (NO38) from amphibian cells was cloned and identified as a member of the nucleoplasmin family (SchmidtZachmann et al. 1987). Protein NO38 shows striking structural similarities with protein B23. Another major nucleolar phosphoprotein, C23 $\left(M_{r} 110000\right)$, was reported to be associated with rDNA and rRNA, and located in the fibrillar and granular component of nucleoli (Olson et al. 1981; Lischwe et al. 1981; Ochs et al. 1983; Spector et al. 1984; Sapp et al. 1986). Protein C23 appears to be identical with nucleolin, a major nucleolar protein of growing eukaryotic cells associated with preribosomes (Bourbon et al. 1983; Escande-Geraud et al. 1986; Herrera and Olson 1986). It appears that $\mathrm{C} 23$ /nucleolin is a component of both nucleolar chromatin as well as ribosomal precursor particles. Nucleolin/C23 has recently been cloned (Lapeyre et al. 1987).

In this review, we present some of the molecular characteristics of autoantigens reactive with antinucleolar antibodies from patients with systemic autoimmune diseases, mostly with systemic sclerosis (scleroderma), which have recently been identified in our laboratories and by other investigators. We show the location of four nucleolar autoantigens (RNA polymerase I, PM-Scl, 7-2 RNP and U3-RNP-associated fibrillarin) by immunofluorescence microscopy in normal and actinomycin D-inactivated nucleoli as well as their topology in nucleolar subcompartments by electron microscopic immunocytochemistry and present new information on nucleolar structure and function obtained by human autoantibodies. These antibodies have proved to be amazingly specific for certain systemic autoimmune diseases (Reimer et al. 1987c) suggesting that the autoimmune responses may be antigen driven. The knowledge of the identity of nucleolar autoantigens should be of considerable interest for the study of mechanisms responsible for elucidation of autoimmune responses characteristic of defined disease entities.

\section{Autoantibodies to RNA polymerase I}

RNA polymerase I is an enzyme complex selectively transcribing the nucleolar genes (reviewed by 
Rose et al. 1983). The information concerning the exact location of RNA polymerase I within the different nucleolar subcompartments and the molecular composition of the enzyme complex is still incomplete. High resolution autoradiographic studies following pulse-labeling of cells with radioactive precursors suggested that transcription of rRNA genes takes place in the dense fibrillar component, and possibly also at the periphery of the fibrillar centers (Fakan 1978; Thiry et al. 1985). By contrast, in-situ hybridisation with radioactive rRNA probes and selective DNA staining with osmium-amine Feulgen-like reaction, DNA (including rDNA) could be detected only in the fibrillar centers (for reviews see Hernandez-Verdun 1983; Goessens 1984). Recently, RNA polymerase I molecules were detected exclusively in the fibrillar centers of rat hepatocytes nucleoli by electron microscopic immunocytochemical techniques using rabbit antibodies specific for RNA polymerase I (Scheer and Rose 1984). These results indicated that transcriptionally active rRNA genes may be confined to the fibrillar centers.

In a recent study on the specificity of autoantibodies in scleroderma (Reimer et al. 1987a) three percent of patients were shown to produce punctate nucleolar staining by immunofluorescence in all tissue culture cells investigated so far (Fig. 1a). In dividing cells, prominent staining of the nucleolar organizing regions (NOR) was observed. In 5,6dichloro- $\beta$-D-ribofuranosylbenzimidazole (DRB) and actinomycin D-segregated nucleoli, immunofluorescence staining was exclusively localized in the fibrillar regions with staining being most prominent in small crescents at the outermost margin of the fibrillar regions in actinomycin D-segregated nucleoli (Fig. 1c). The staining properties by immunofluorescence of these scleroderma autoantibodies were identical to those described with the rabbit antibodies specific for RNA polymerase I (Scheer and Rose 1984; Scheer et al. 1984). By electron microscopic immunocytochemistry using the "pre-embedding" technique and human antiRNA pol I autoantibodies, gold antigen-antibody complexes were detected in the fibrillar centers but not in the granular component or dense fibrillar component (Reimer et al. 1987a). Using ultrathin frozen sections of cells as substrates in the "postembedding" label technique (Tokuyasu 1980; Scheer and Raska 1987), gold-antibody-antigen complexes were also located in the fibrillar centers and appeared to be essentially absent from the dense fibrillar or granular component of nucleoli (Fig. 1 e). The same result was obtained with rabbit antibodies specific for RNA polymerase I (Fig. 2).
Since labeling on ultrathin frozen sections provides optimal accessibility of epitopes, the absence of gold label over the dense fibrillar component and granular component most likely indicates the absence of RNA polymerase I in these nucleolar subcompartments indicating that rDNA transcription predominantly (if not exclusively) takes place in the fibrillar centers of nucleoli. This concept has recently been further substantiated by showing that a monoclonal anti-DNA antibody stained the fibrillar centers but not the dense fibrillar component or the granular component of nucleoli indicating the presence of DNA (including rDNA) in the fibrillar centers only (Scheer et al. 1987). The knowledge of the exact site of rDNA transcription within the nucleolus should be of considerable importance for an understanding of the functional organization of the nucleolus.

RNA polymerase I is a complex enzyme which in Morris hepatoma 3942A is composed of eight subunits with mol wt $\left(\mathrm{M}_{\mathrm{r}}\right)$ from 190000 to 17500 (Rose et al. 1981). The $M_{r} 42000$ and 46000 subunits were shown to have protein kinase activity (Rose et al. 1981). In a recent publication, we reported that both human autoimmune and experimentally raised rabbit antibodies against RNA pol I precipitated a complex particle composed of at least 13 polypeptides with mol wts $\left(\mathrm{M}_{\mathrm{r}}\right)$ ranging from 210000 to 12500 (see also Fig. 6, lane 2). The complex contained four phosphoproteins with $M_{r} 180000,80000,64000$ and 18000 but no tightly bound RNA. It is conceivable that this protein complex not only contains the genuine subunits of RNA polymerase I but also associated transcription factors important for initiation and/or termination of rDNA transcription (e.g. Wandelt and Grummt 1983; Grummt et al. 1985). Scleroderma autoantibodies reactive with RNA pol I should be valuable probes in future analyses of the "native" composition of this nucleolar enzyme and its association with factors modifying and controlling rRNA gene transcription.

Functional evidence of the interaction between scleroderma antibodies producing punctate nucleolar staining and RNA polymerase I was obtained by demonstrating that these antibodies selectively inhibited pre-rRNA synthesis when microinjected into Xenopus laevis oocyte nuclei (Reimer et al. 1987a). The inhibitory effect of antiRNA pol I autoantibodies on the enzyme activity suggested that the antigenic determinants reside on a functional important component of the enzyme complex, possibly the catalytic center. In a more recent study, it was shown that microinjection of human autoantibodies to RNA pol I into mitotic 

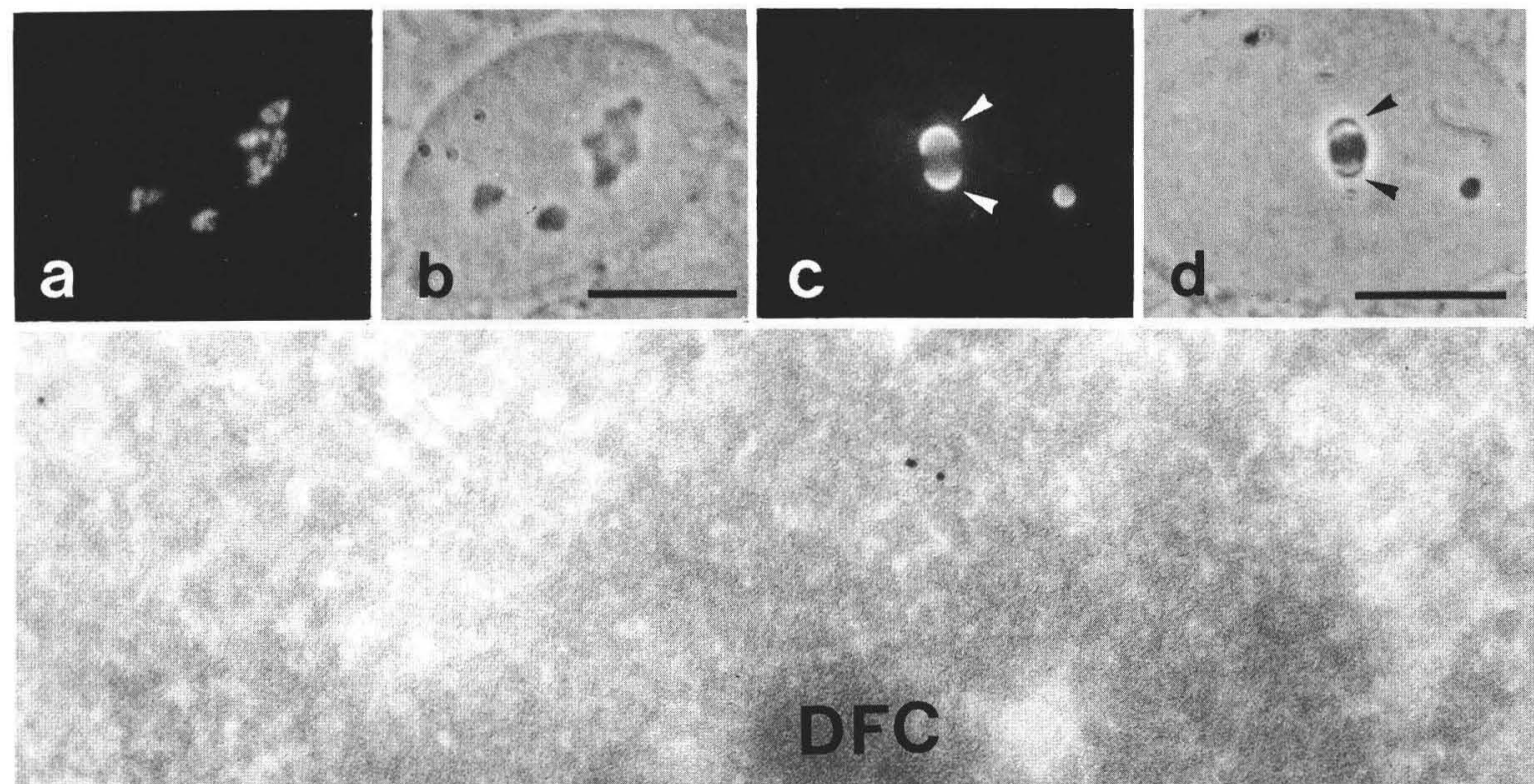

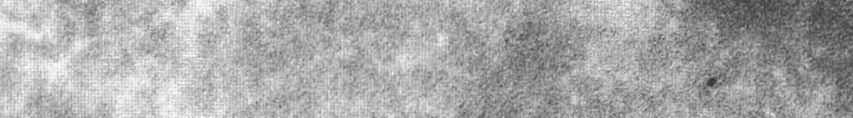

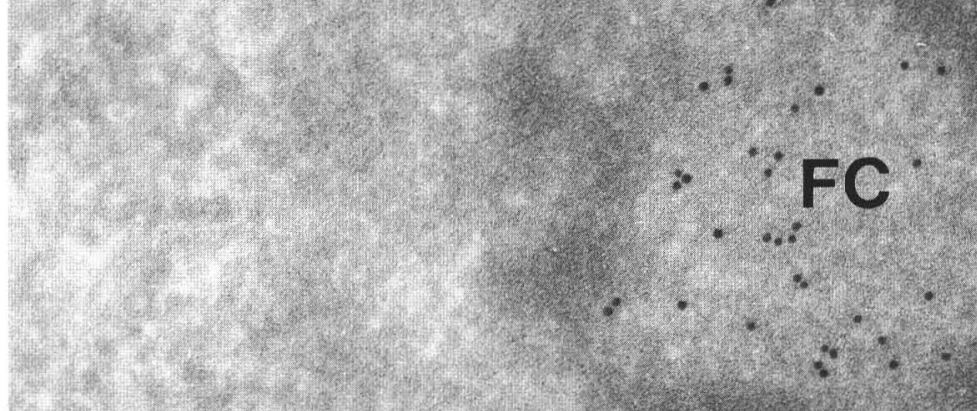

\section{GC}

\section{$\mathrm{Ch}$}
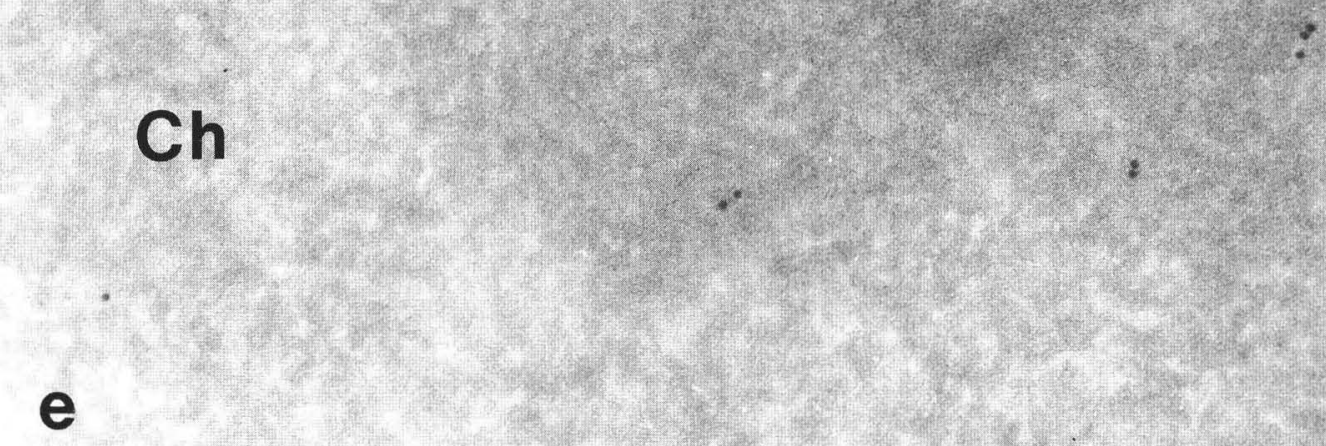
rat kangaroo PtK2 cells inhibited reformation of nucleoli in the daughter cells (Benavente et al. 1987). These antibodies specifically inhibited the telophasic coalescence of "prenucleolar bodies" around the chromosomal nucleolar organizing regions (NOR) which normally leads to the reappearence of nucleoli. RNA pol I antibodies, however, did not interfere with normal mitotic progression or early steps of nucleologenesis or the formation of these "prenucleolar bodies" which consisted of structures resembling the nucleolar "dense fibrillar component" by electron microscopy. Moreover, the prenucleolar bodies could be specifically stained by human autoantibodies and murine monoclonal antibodies against the protein "fibrillarin" previously shown to localize in the fibrillar regions of nucleoli (Hadjiolova et al. 1986: Reimer et al. 1987b). Segregation and partial disintegration of nucleolar structures by RNA pol I antibodies microinjected into interphase cell nuclei was also observed (Benavente et al., unpublished work). These experiments not only gave functional evidence of the interaction of human autoantibodies against RNA pol I with the enzyme complex in the living cell but also insight into basic mechanisms of nucleologenesis suggesting a crucial role of RNA polymerase I and/or the transcriptional complexes for the structural organization and integrity of transcriptionally active nucleoli in eukaryotic cells.

\section{Autoantibodies reactive with the nucleolar particle PM-Scl (Polymyositis-Scleroderma antigen)}

In a previous clinical publication, a novel antigenantibody system was described by immunodiffusion which was characteristic of certain patients with polymyositis/scleroderma overlap syndromes and hence termed the PM-Scl system (Reichlin et al. 1984). The PM-Scl antibody specificity was recently further investigated and the reactive antigen partially characterized in our laboratories (Reimer et al. 1986). Typically, anti-PM-Scl antibodies produced homogeneous nucleolar staining in cells from a variety of different species as shown for HeLa cells in Fig. 3 a. In actinomycin D-inactivated nucleoli, anti-PM-Scl staining was mainly localized in the granular regions of segregated nucleoli (Fig. 3c). When DRB-pretreated cells were incubated with anti-PM-Scl-antibodies, immunofluorescence was evenly distributed throughout the nucleoplasm without any "necklace" staining (Reimer et al. 1986). These "necklace" structures are known to contain RNA polymerase I (Scheer et al. 1985) and also the nucleolar protein "fibrillarin" (Ochs et al. 1985; Reimer et al. 1987b) but lack the granular component containing the preribosomal particles (Scheer et al. 1984; Hügle et al. 1985a).

By electron microscopic immunocytochemistry, anti-PM-Scl antibodies predominantly stained the granular component of nucleoli in rat liver hepatocytes (Fig. 3 e and f). Since the granular component is the site of ribosomal assembly and packaging, this location suggests a relationship of the PM-Scl antigen to preribosomes.

On a molecular level, anti-PM-Scl antibodies immunoprecipitated 11 polypeptides with mol wts $\left(M_{r}\right)$ ranging from 110000 to 20000 when incubated with ${ }^{35} \mathrm{~S}$-methionine-labeled HeLa cell proteins (see Fig. 6, lane 3). The $M_{r} 80000$ and 20000 polypeptides were phosphorylated. Unfortunately, RNA could as yet not be identified in the immunoprecipitates. Therefore, the nature of the PM-Scl antigen is still somewhat ambiguous. By immunoblotting, most anti-PM-Scl antisera reacted with polypeptides of $M_{r} 100000$ and/or 80000 (Reimer et al. 1986).

Experiments using autoantibodies from certain patients with polymyositis/scleroderma overlap syndromes should reveal more information of the exact nature of the PM-Scl particle and its role in ribosome biogenesis.

\section{Autoantibodies to 7-2 ribonucleoprotein}

In two previous publications (Reddy et al. 1983; Hashimoto and Steitz 1983) human autoimmune

Fig. 1 a-e. Immunolocalization of scleroderma IgG autoantibodies to RNA pol I in nucleoli from different cell species. Immunofluorescence microscopy of HeLa cells (frame a) after staining with scleroderma antibodies to RNA pol I reveals numerous dot-like substructures within the nucleolus. The corresponding phase-contrast micrograph is shown in frame (b). After exposure of Vero cells (a virus-transformed monkey cell line) to actinomycin D, two fluorescent crescents are located at the periphery of the phase-light fibrillar component (arrowheads). Frame (e) shows the labeling of an ultrathin frozen sections of cultured HeLa cells with autoantibodies to RNA pol I. A cell pellet was fixed in $4 \%$ formaldehyde for $60 \mathrm{~min}$, washed in PBS, incubated in $2.1 \mathrm{M}$ sucrose and shock-frozen in liquid nitrogen. Cryosections were cut and incubated with antibodies essentially as described by Tokuyasu (1980). Secondary antibodies specific for human IgG coupled to $10 \mathrm{~nm}$ gold particles were used as the detecting reagent. Gold particles are enriched over the large fibrillar center $(F C)$ with little staining of the dense fibrillar $(D F C)$ or granular component $(G C)$. Ch, chromatin. Bars $=10 \mu \mathrm{m}(\mathbf{b}$ and $\mathbf{d}), 0.1 \mu \mathrm{m}(\mathbf{e})$ 


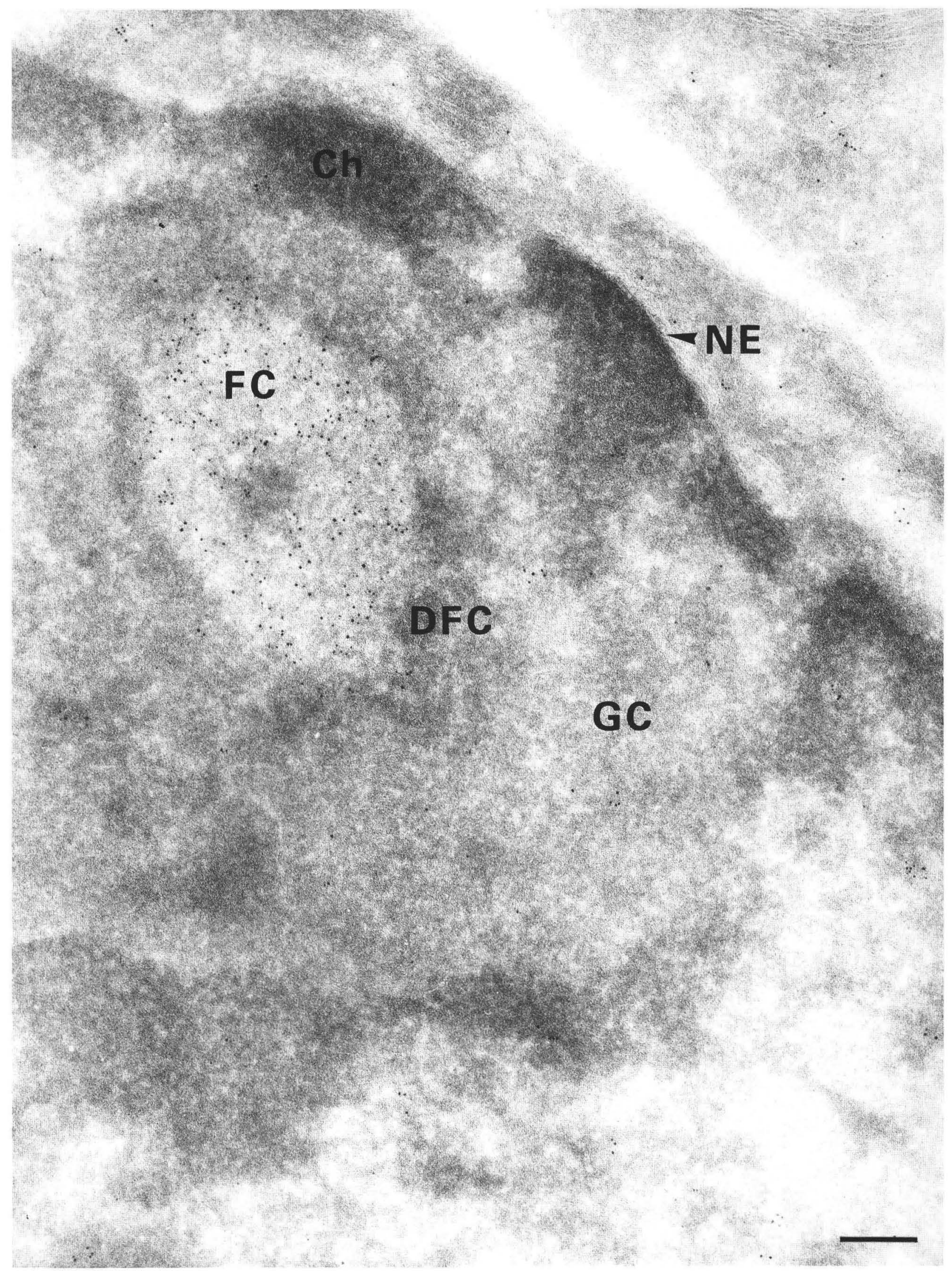

Fig. 2. Binding of rabbit IgG antibodies against RNA polymerase I to the fibrillar centers of rat PC12 nucleoli. Similar preparation and technique as shown in Fig. 1e. Gold particles are concentrated over the fibrillar center $(F C)$ and virtually absent from the granular $(G C)$ and dense fibrillar component $(D F C)$. Ch, nucleolus-associated heterochromatin; $N E$, nuclear envelope. Bar $0.2 \mu \mathrm{m}$ 
sera (anti-To and anti-Th) were used to immunoprecipitate a ribonucleoprotein complex containing 7-2 RNA. This small RNA was originally characterized as a nucleolar RNA species in biochemical fractionation experiments (reviewed by Busch et al. 1982) and was shown to be among RNA polymerase III transcripts (Hashimoto and Steitz 1983). In addition, anti-To antibodies precipitated a $7-2 *$ RNA species which has a slightly lower electrophoretic mobility on urea-polyacrylamide gels than 7-2 RNA. It was suggested that this difference in mobility might reflect a few additional nucleotides on the 3'-end of the 7-2 RNA molecule. This 7-2* RNA appears to be also complexed with the SS-B/La ribonucleoprotein (Hashimoto and Steitz 1983). Using scleroderma antibodies, we recently immunoprecipitated at least one protein $\left(M_{r} 40000\right)$ possibly associated with 7-2 RNA (Fig. 6, lane 4). It was clearly shown that cellular RNA was not immunoreactive whereas anti-7-2 RNP antibodies precipitated a $M_{r} 40000$ protein from RNase-pretreated cell extract (Reimer et al. 1987d).

By immunofluorescence, serum To containing antibodies to 7-2 RNP produced bright nucleolar staining (Fig. $4 \mathrm{a}$ ). In actinomycin D-segregated nucleoli, 7-2 RNP was localized in the granular regions (Fig. 4c). In transcriptionally active nucleoli of rat liver hepatocytes, 7-2 RNP was exclusively present in the granular component (Fig. 4e). 7-2 RNP may be related to a $M_{r} 40000$ nucleolar protein ("ribocharin") described in Xenopus laevis and other amphibia which appears to be specific to precursor particles of the large ribosomal subunit (Hügle et al. 1985a). Another nucleolar protein (B23) of rat hepatoma and rat liver cells with a mol wt $\left(M_{r}\right) 37000$ was also mainly localized in the granular component of the nucleolus (Olson et al. 1981; Ochs et al. 1983; Spector et al. 1984). Protein B23 is believed to be associated with ribosomal precursor particles. Whether 7-2 RNP, ribocharin and protein B23 are related is not known. However, it is tempting to suggest that 7-2 RNP may be involved in the assembly of ribosomal particles, their maturation and/or transport, i.e. stages of ribosome biogenesis that have been mapped to the granular component of the nucleolus.

\section{Autoantibodies to U3-RNP associated fibrillarin}

In previous studies certain scleroderma sera precipitated a ribonucleoprotein particle containing U3RNA (Reddy et al. 1983). U3 is a highly conserved RNA species which was shown to be composed of 217 nucleotides in human (Suh et al. 1986). U3 is the only nucleolar RNA known to have a trimethylated guanosin cap at its $5^{\prime}$ end (Busch et al. 1982; Lührmann et al. 1982). The nucleolar localization of U3 and its association with 28-35S RNA (Prestayko et al. 1970; Zieve and Penman 1976) and partial complementarity between U3 and rRNA suggested an involvement in rRNA processing. It was postulated that U3 mediates the cleavage separating $5.8 \mathrm{~S}$ from the so called internal transcribed spacer II of pre-rRNA (Bachellerie et al. 1983; Crouch et al. 1983; Tague and Gerbi 1984).

The protein of the U3-RNP particle bearing the antigenic determinants was recently shown to be a basic (pI 8.5) $\mathrm{M}_{\mathrm{r}} 34000$ nucleolar protein rich in $\mathrm{N}^{\mathrm{G}}, \mathrm{N}^{\mathrm{G}}$-dimethylarginine and glycine, some of these residues clustering at the $\mathrm{N}$-terminus of the molecule (Lischwe et al. 1985). Immunolocalization of this protein by immunofluorescence and electron microscopy by scleroderma autoantibodies was exclusively in the fibrillar regions of nucleoli and hence this protein was named fibrillarin (Ochs et al. 1985). "Fibrillarin" shows many characteristics of a previously described nucleolar protein (B36) which was isolated from the slime mold Physarum polycephalum (Christensen et al. 1977; Christensen et al. 1986). Scleroderma autoantibodies against fibrillarin recognize epitopes which are well-conserved during evolution and occur not only in nucleoli from a variety of animal species but also from plant cells (Reimer et al. 1987b; Vaughan 1987). Figure 5a shows nucleolar localization of scleroderma autoantibodies reactive with fibrillarin. In actinomycin D-segregated nucleoli, immunofluorescence staining was confined to the fibrillar regions (Fig. 5c). Using the "post-embedding" immunogold label technique, we confirmed the specific location of fibrillarin in the dense fibrillar component of transcriptionally active nucleoli from cultured HeLa cells (Fig. 5e).

Recently, a monoclonal autoantibody was derived from spleen cells of NZB/NZW F1 mouse from a strain with a disease resembling human SLE which was directed against the U3-RNP associated fibrillarin (Reimer et al. 1987b). This monoclonal antibody shared the same immunological characteristics as certain scleroderma antibodies. By using this monoclonal antibody and human anti-U3RNP autoantibodies in immunoprecipitation, Parker and Steitz (1987) found that the precipitated ribonucleoprotein contained four nonphosphorylated proteins of $\mathrm{M}_{\mathrm{r}} 36000,30000,13000$ and 12500 and two phosphorylated proteins of $\mathrm{M}_{\mathrm{r}} 74000$ and 59000 . The $\mathrm{M}_{\mathrm{r}} 36000$ protein most likely corresponds to the $\mathrm{M}_{\mathrm{r}} 34000$ nucleolar pro- 

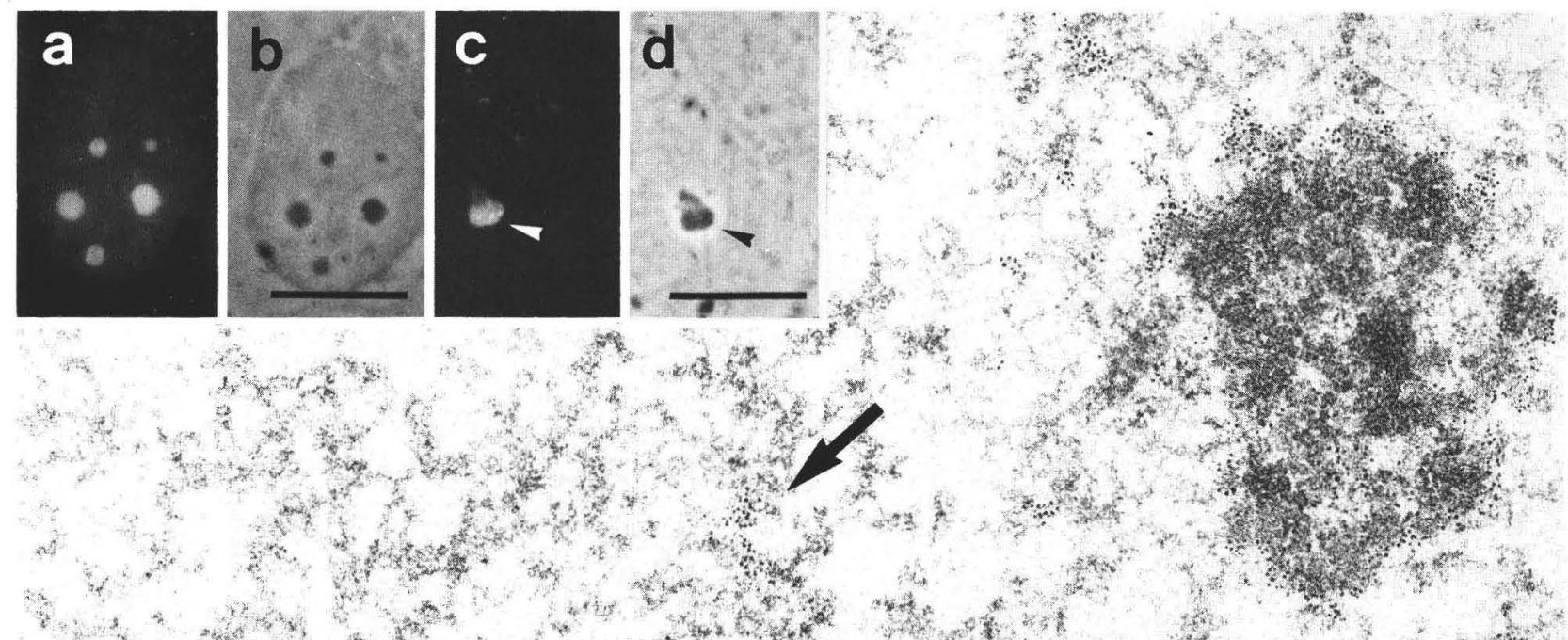

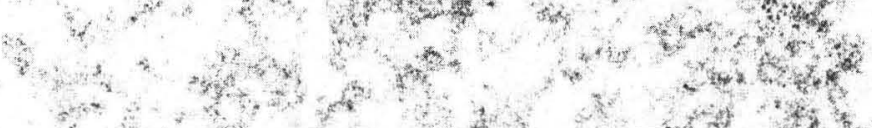

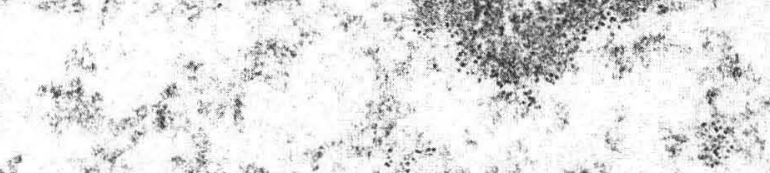

(2) 18.73

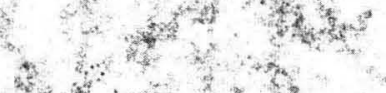

Mot tont

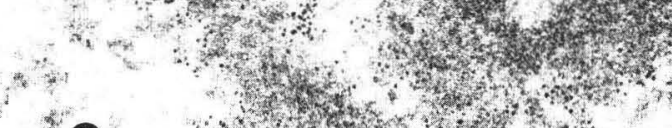

e

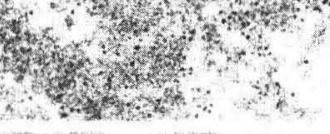

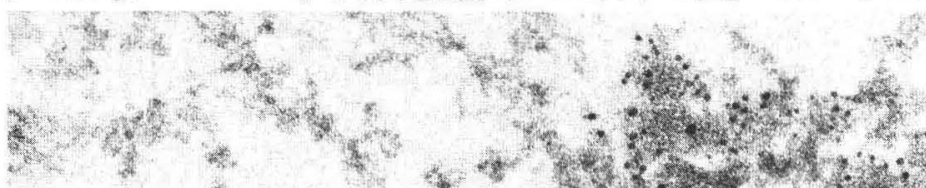
Why $7^{3}$ in

$x$
$x$
$x+2$

the? aty $42 \times 3 \quad 3$

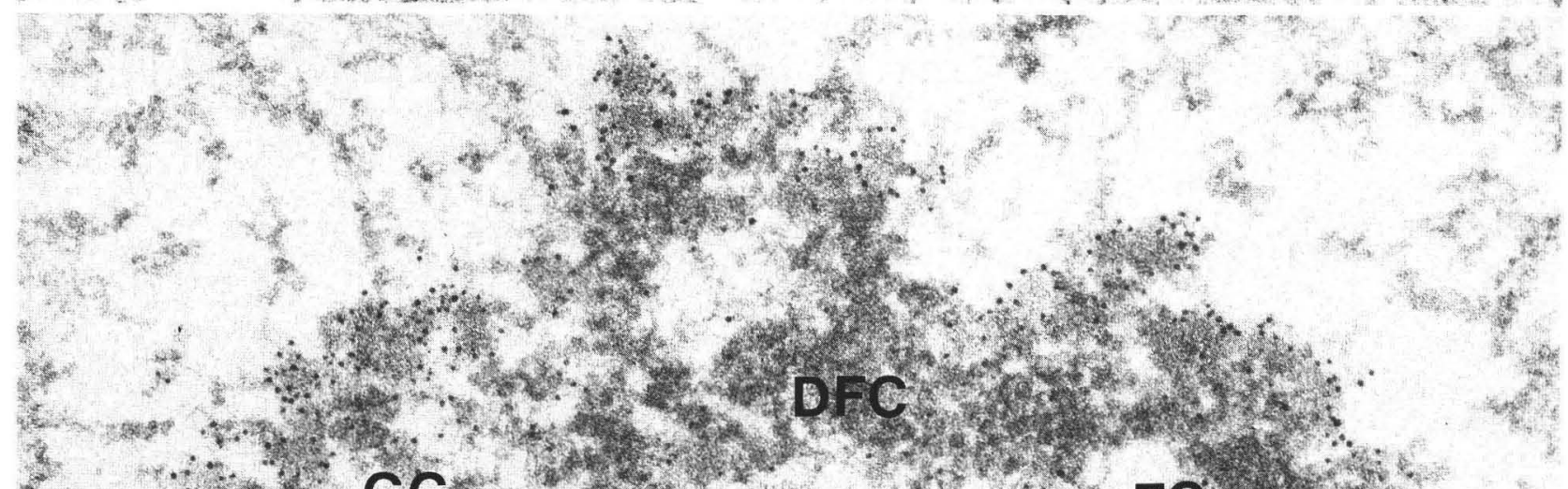

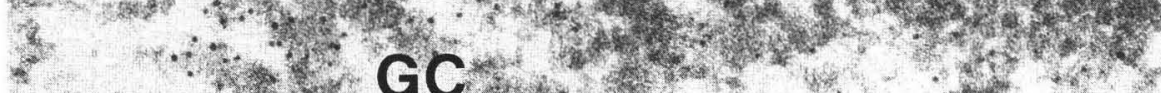

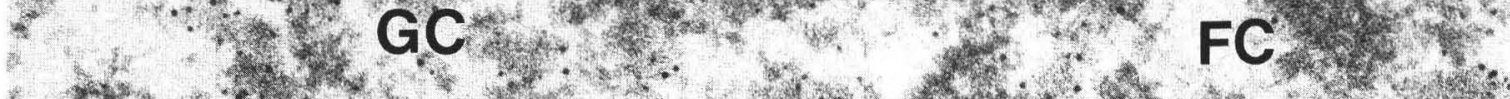

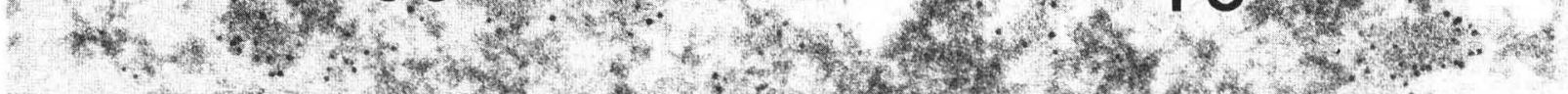

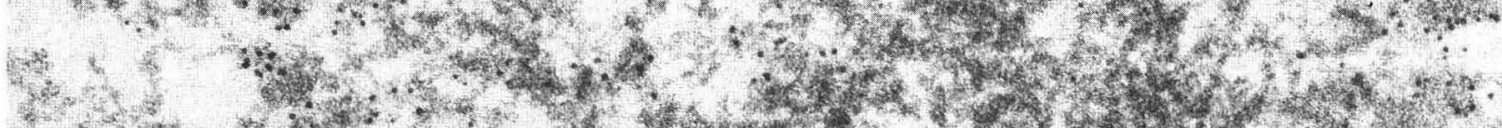

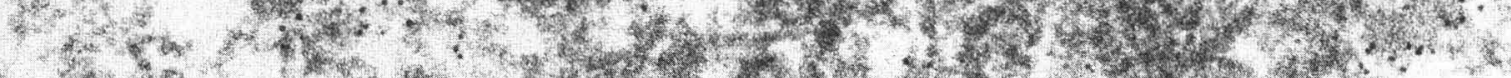

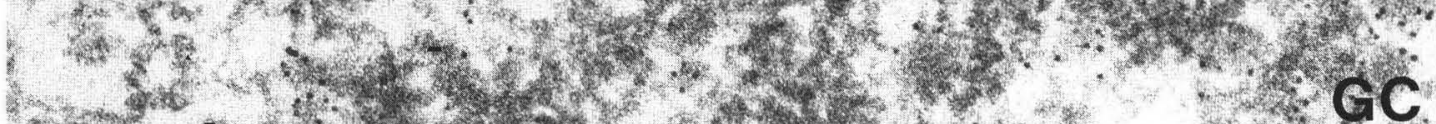

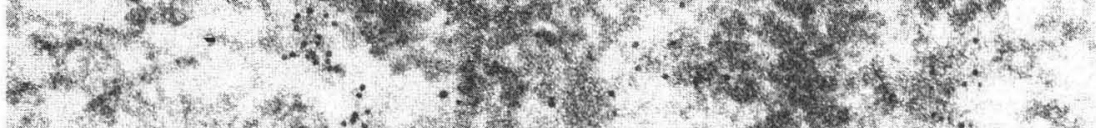

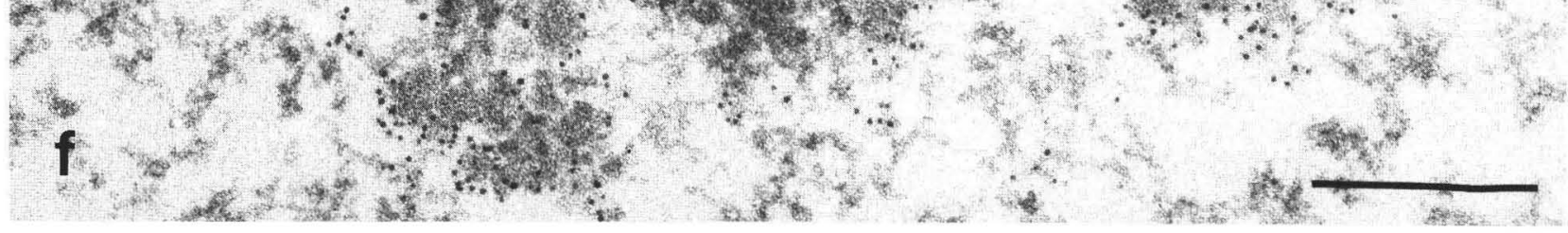

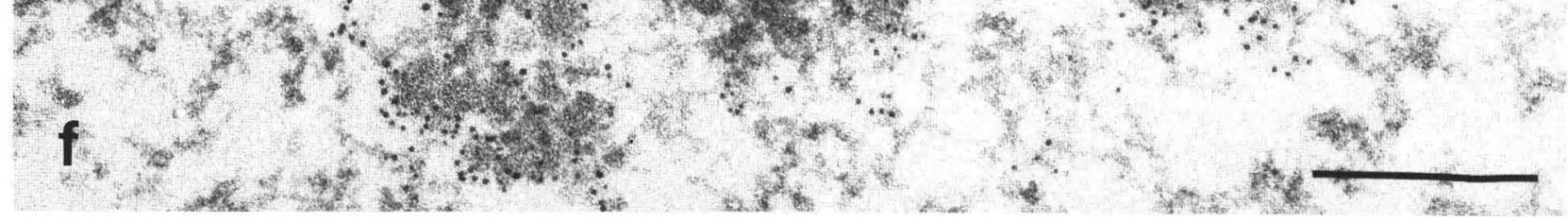

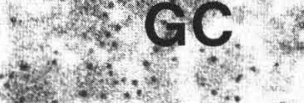




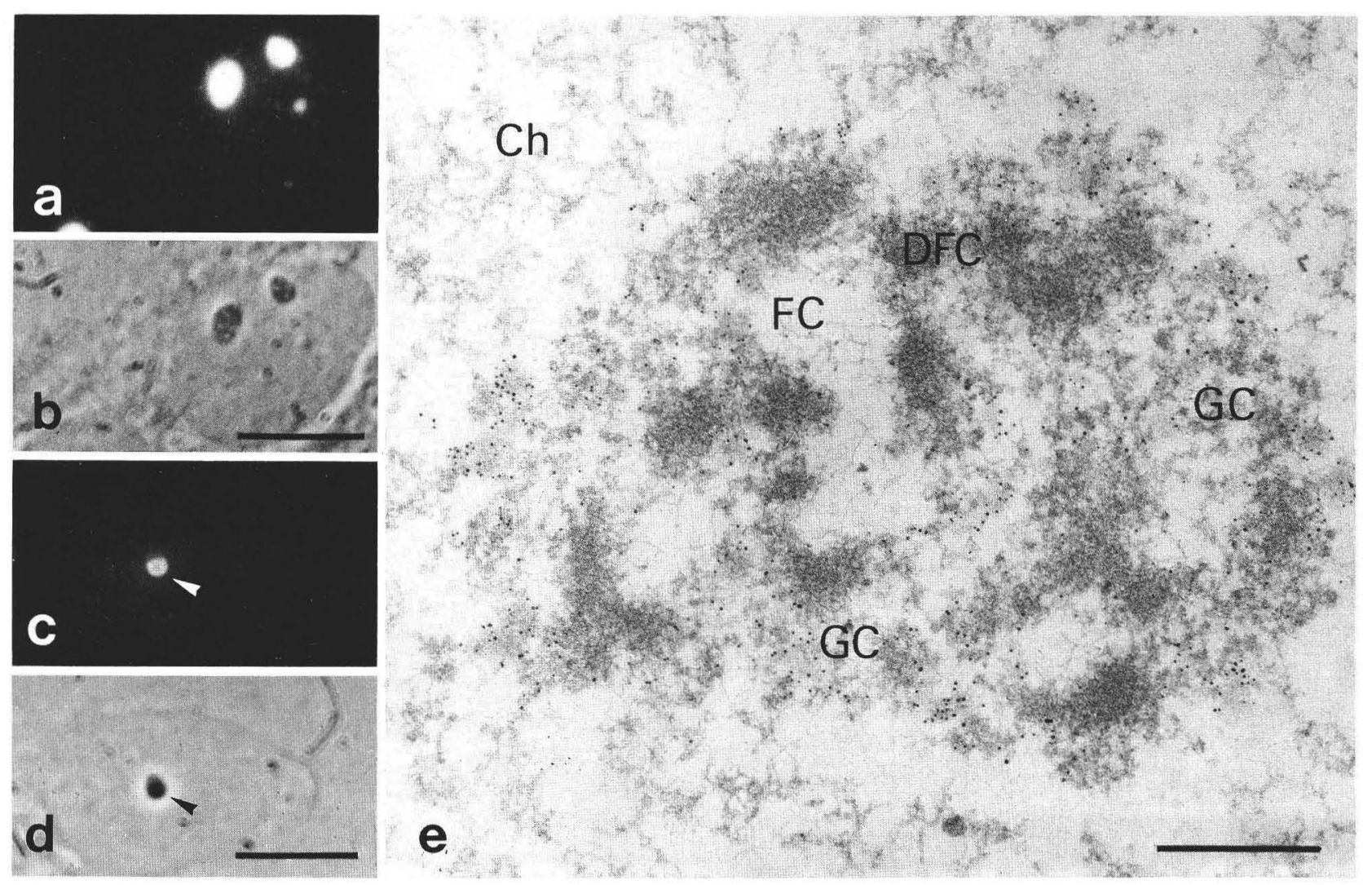

Fig. 4a-e. Immunolocalization of 7-2 ribonucleoprotein. Immunofluorescence staining of a HeLa cell (frame a) and actinomycin D-treated Vero cells (c) after incubation with autoimmune antibodies to 7-2 RNP. Bright homogeneous staining is present within the HeLa cell nucleoli. In the actinomycin-segregated Vero cell nucleolus of frame (c), only the dark granular region (arrows) is intensely stained. The cells are also shown in phase-contrast (frames b and $\mathbf{d}$ ). By electron microscopic immunocytochemistry (frame e) in the "pre-embedding" technique, colloidal gold indicating tissue-bound antibody-antigen complexes is selectively enriched over the granular component $(G C)$ and absent from the dense fibrillar component $(D F C)$ or fibrillar centers $(F C)$. Bars $=10 \mu \mathrm{m}(\mathbf{b}, \mathbf{d}), 0.2 \mu \mathrm{m}(\mathbf{e})$

tein (fibrillarin) recognized by specific scleroderma and monoclonal antibodies in immunoblots. Figure 6 , lane 6 shows the $M_{r} 34000$ protein antigen from purified rat liver nucleoli recognized by a reference scleroderma serum in immunoblotting.

Recent sequencing data and structural analysis of U3-RNA by Parker and Steitz (1987) showing complementarity between single-stranded regions of U3 and pre-rRNA sequences suggested that U3RNA might be involved in processing events near the $3^{\prime}$ end of pre-rRNA. Localization of U3-RNP associated fibrillarin in the dense fibrillar compo- nent of transcriptionally active nucleoli (Fig. 5; see also Ochs et al. 1985), the site where early stages of rRNA processing and preribosomal particle assembly are supposed to take place (Hadjiolov 1985) would be in agreement with an involvement of U3-RNP in early stages of rRNA processing. However, high resolution autoradiographic studies after in vivo labeling of U3-RNA showed silver grains predominantly over the granular component (Lacoste-Royal and Simard 1984). Immunolocalization of $\mathrm{m}_{3} \mathrm{G}$-caps of U-RNAs within the nucleolus with a specific rabbit antibody (Lühr-

Fig. 3a-f. Immunolocalization of PM-Scl antigen. Immunofluorescence staining of nucleoli in HeLa cells with human anti-PM-Scl antibodies. Nucleoli demonstrate a bright and homogeneous fluorescence (frame a). In actinomycin D-segregated nucleoli, staining of the phase dark granular component (arrows) is observed (frame c). The cells are also shown by phase-contrast microscopy (frames b and d). Binding of anti-PM-Scl antibodies to nucleoli of hepatocytes from regnerating rat liver by the "pre-embedding" immunogold electron microscopic technique is shown in frames (e) and (f) (see also Reimer et al. 1986). Frame (e) presents an overview with two nucleoli and surrounding chromatin. Clusters of gold particles are also present in the nucleoplasm (arrows in frame e). Frame (f) shows at high magnification a portion of a nucleolus. The $5 \mathrm{~nm}$ gold particles (small black dots) representing gold-antibody-antigen complexes are selectively enriched over the granular component $(G C)$. The dense fibrillar component $(D F C)$ and fibrillar centers $(F C)$ are virtually free of gold particles. Bars $=10 \mu \mathrm{m}(\mathbf{b}, \mathbf{d}), 0.5 \mu \mathrm{m}(\mathbf{e})$ and $0.2 \mu \mathrm{m}(\mathbf{f})$ 


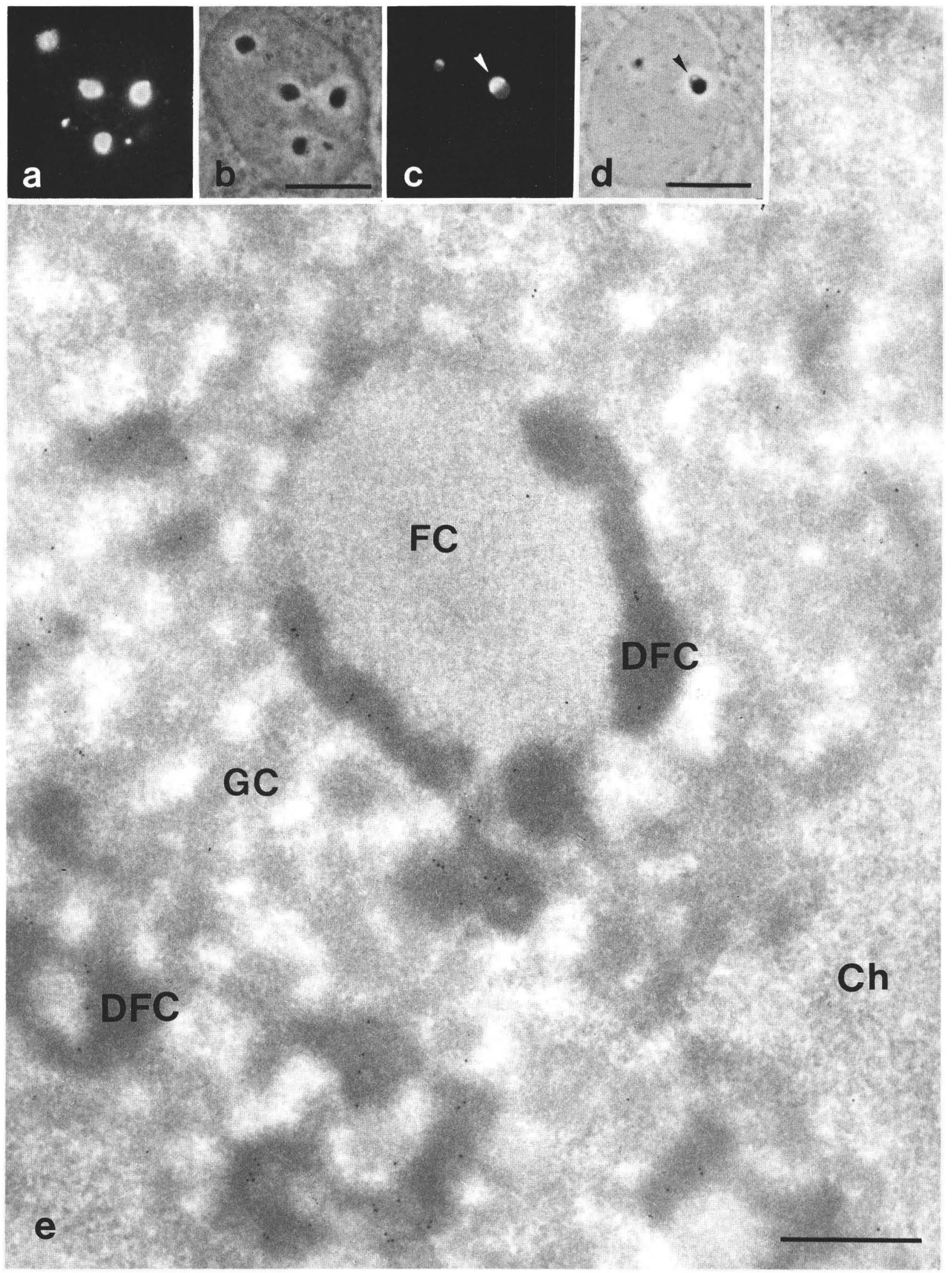




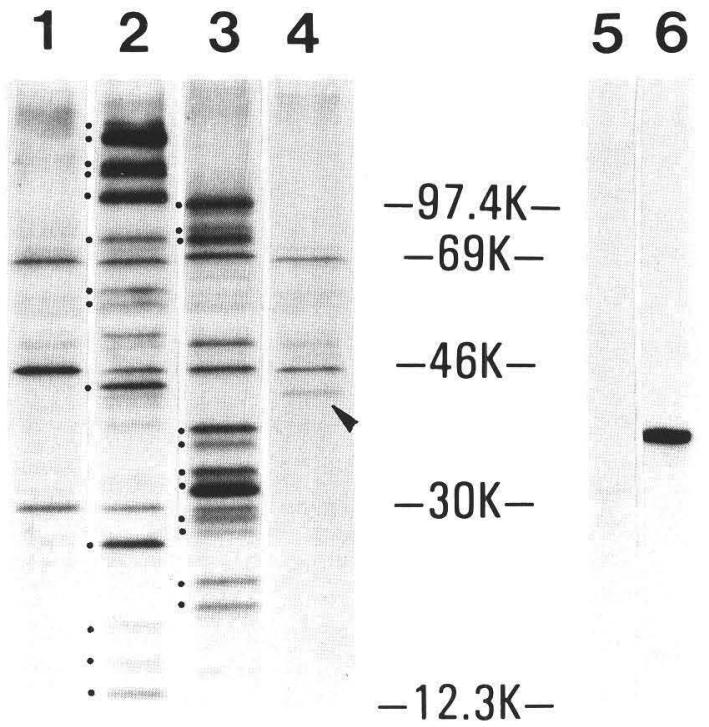

Fig. 6. Autoradiogram of ${ }^{35} \mathrm{~S}$-methionine-labeled HeLa cell proteins immunoprecipitated by various antinucleolar autoantibodies followed by SDS-polyacrylamide $(17.5 \%)$ gel electrophoresis (lanes 1-4). HeLa cells were grown in monolayers and in vivo-labeled with ${ }^{35} \mathrm{~S}$-methionine. Cell extracts were used as antigen sources for protein A-facilitated immunoprecipitation with the various autoantibodies and controls (Reimer et al. 1987a). Lane 1 represents the proteins non-specifically precipitated with $\operatorname{IgG}$ from normal human serum. Lane 2 shows the polypeptides immunoprecipitated with scleroderma anti-RNA pol I antibodies. At least 13 polypeptides with mol wts $\left(M_{r}\right)$ ranging from 210000 to 12500 are present in the immunoprecipitates and are marked by black dots. Anti-PM-Scl antibodies from a patient with polymyositis/scleroderma overlap syndrome precipitate different polypeptides with $\mathrm{M}_{\mathrm{r}}$ ranging from 110000 to 20000 as shown in lane 3 (black dots). Antibodies against 7-2 RNP precipitate a $\mathrm{M}_{\mathrm{r}} 40000$ protein (lane 4, arrowhead). Note that all other polypeptides present in lane 4 are also precipitated by normal IgG's (lane 1). Immunoblots with scleroderma antibodies to fibrillarin are shown in lane 6 and with normal control serum in lane 5. Proteins from isolated rat liver nucleoli were separated by SDS-polyacrylamide gelelectrophoresis and electrophoretically transferred onto nitrocellulose (for details see Reimer et al. 1987b). Nitrocellulose strips were incubated with normal control serum (lane 5) and autoimmune serum containing antibodies against fibrillarin (lane 6). The immunoreaction was visualized by a second incubation with ${ }^{125}$ I protein $\mathrm{A}$ follwed by autoradiography. A polypeptide with $M_{r} 34000$ is recognized by the scleroderma antibodies

mann et al. 1982) also demonstrated that U3 is mainly located in the granular component (Scheer, unpublished work). These observations support the notion that U3 is preferentially involved in late stages of rRNA processing (see also Bachellerie et al. 1983; Crouch et al. 1983; Tague and Gerbi 1984).

\section{Conclusions}

Four distinct nucleolar proteins or RNA-protein complexes have recently been identified as targets of human autoimmune antibodies. These autoantigens are RNA polymerase I, PM-Scl (a particle possibly related to preribosomes), 7-2 RNP and fibrillarin (a U3-RNP associated protein). The four different nucleolar autoantigens could be assigned to distinct nucleolar subcompartments by light and electron microscopic immunocytochemistry. RNA polymerase I was located in the fibrillar centers, PM-Scl antigen and 7-2 RNP in the granular component and fibrillarin in the dense fibrillar component. Experimental evidence suggests that these naturally occurring antibodies could be helpful tools in further studying nucleolus structure and functions as well as molecular mechanisms involved in ribosome biogenesis.

From a clinical viewpoint, we believe that it is important to identify the nature of reactive autoantigens in systemic autoimmune diseases in order to answer questions concerning the mechanisms which render conserved ubiquitous cellular proteins immunogenic. Revealing such mechanisms in return could give clues with regard to the etiology of certain systemic rheumatic diseases. Ribosome biogenesis, a highly dynamic process with its many well-defined intermediate biological steps related to specific nuclear structures could be amenable for such studies.

\section{References}

Bachellerie J-P, Michot B, Raynal F (1983) Recognition signals for mouse pre-rRNA processing. Mol Biol Rep 9:79-86

Benavente R, Krohne G, Stick R, Franke WW (1984) Electron microscopic immunolocalization of a karyoskeletal protein of molecular weight 145000 in nucleoli and prenucleolar bodies of Xenopus laevis. Exp Cell Res 151:224-235

Benavente R, Rose KM, Reimer G, Hügle-Dörr B, Scheer U (1987) Inhibition of nucleolar reformation after microinjection of antibodies to RNA polymerase I into mitotic cells. $\mathrm{J}$ Cell Biol 105 (in press)

Bernstein RM, Steigerwald JC, Tan EM (1982) Association of antinuclear and antinucleolar antibodies in progressive systemic sclerosis. Clin Exp Immunol 48:43-51

Black DL, Chabot B, Steitz JA (1985) U2 as well as U1 small nuclear ribonucleoproteins are involved in premessenger RNA splicing. Cell 42: 737-750

Fig. 5a-e. Immunolocalization of U3-ribonucleoprotein-associated "fibrillarin". Immunofluorescence staining with scleroderma autoantibodies to U3-RNP using HeLa cells (frame a) and Vero cells pretreated with actinomycin D (frame c) as substrates. In the actinomycin D-segregated nucleolus in frame (c) immunofluoresence is confined to the phase-light fibrillar region (arrows). For comparison, the cells are also shown by phase-contrast (frames b and d). By electron microscopic immunocytochemistry using the "post-embedding" immunogold label technique, antibodies to U3-RNP exclusively localize in the dense fibrillar component $(D F C)$ of this nucleolus from a cultured HeLa cell. The fibrillar center $(F C)$ and the granular component $(G C)$ are virtually free of gold particles. Bars $=10 \mu \mathrm{m}(\mathbf{b}, \mathbf{d}), 0.5 \mu \mathrm{m}(\mathbf{e})$ 
Bourbon HM, Bugler B, Caizergues-Ferrer M, Almaric F, Zalta JP (1983) Maturation of a $100 \mathrm{kDa}$ protein associated with preribosomes in Chinese hamster ovary cells. Mol Biol Rep 9:39-47

Busch H, Smetana K (1970) The nucleolus. Academic Press, Inc New York, pp 1-626

Busch H, Reddy R, Rothblum L, Choi YC (1982) SnRNAs, snRNPs, and RNA processing. Ann Rev Biochem $51: 617-654$

Busch H (1984) Nucleolar proteins: purification, isolation, and functional analyses. In: Hnilica (ed) Chromosomal nonhistone proteins. CRC Press, Inc, Boca Raton, Florida, pp 233-286

Christensen ME, Beyer AL, Walker B, LeStourgeon WM (1977) Identification of $\mathrm{N}^{\mathrm{G}}, \mathrm{N}^{\mathrm{G}}$-dimethylarginine in a nuclear protein from the lower eukaryote Physarum polycephalum homologous to the major proteins of mammalian $40 \mathrm{~S}$ ribonucleoprotein particles. Biochem Biophys Res Commun 74:621-625

Christensen ME, Moloo J, Swischuk JL, Schelling ME (1986) Characterization of the nucleolar protein, B-36, using monoclonal antibodies. Exp Cell Res 166:77-93

Crouch RJ, Kanaya S, Earl PL (1983) A model for the involvement of the small nucleolar RNA (U3) in processing eukaryotic ribosomal RNA. Mol Biol Rep 9:75-78

Douvas AS, Achten M, Tan EM (1979) Identification of a nuclear protein (Scl-70) as a unique target of human antinuclear antibodies in scleroderma. J Biol Chem 254:10514-10522

Elkon KB, Parnasa AP, Foster CL (1985) Lupus autoantibodies target ribosomal P proteins. J Exp Med 162:459471

Escande-Geraud ML, Azum MC, Tichadou JL, Gas N (1985) Correlation between rDNA transcription and distribution of a $100 \mathrm{kD}$ nucleolar protein in CHO cells. Exp Cell Res $161: 353-363$

Fakan S (1979) High resolution autoradiography studies on chromatin functions. In: Busch $\mathrm{H}$ (ed) The cell nucleus, vol 5: Academic Press Inc, New York, pp 3-53

Francoeur A-M, Peebles CL, Heckman KJ, Lee JC, Tan EM (1985) Identification of ribosomal protein autoantigens. J Immunol 135:2378-2384

Franke WW, Kleinschmidt JA, Spring H, Krohne G, Grund C, Trendelenburg MF, Stoehr M, Scheer U (1981) A nucleolar skeleton of protein filaments demonstrated in amplified nucleoli of Xenopus laevis. J Cell Biol 90:289-299

Goessens G (1984) Nucleolar structure. Int Rev Cytol 87:107-158

Grummt I, Maier U, Öhrlein A, Hassouna N, Bachellerie J-P (1985) Transcription of mouse rDNA terminates downstream of the $3^{\prime}$ end of 28S RNA and involves interaction of factors with repeated sequences in the 3'spacer. Cell $43: 801-810$

Guldner HH, Szostecki C, Vosberg HP, Lakomek HJ, Penner E, Bautz FA (1986) Scl 70 autoantibodies from scleroderma patients recognize a $95 \mathrm{kDa}$ protein identified as DNA topoisomerase I. Chromosoma (Berl) 94:132-138

Hadjiolov AA (1985) The nucleolus and ribosome biogenesis. Cell biol monographs, vol 12, Springer, Berlin Heidelberg New York Tokyo, pp 1-268

Hadjiolova K, Rose KM, Scheer U (1986) Immunolocalization of nucleolar proteins after D-galactosamine-induced inhibition of transcription in rat hepatocytes. Exp Cell Res $165: 481-493$

Hashimoto C, Steitz JA (1983) Sequential association of nucleolar 7-2 RNA with two different autoantigens. J Biol Chem $258: 1379-1382$
Hernandez-Verdun D, Bouteille M, Ege T, Ringertz NR (1979) Fine structure of nucleoli in micronucleated cells. Exp Cell Res 124:223-235

Hernandez-Verdun D (1983) The nucleolar organizer region. Biol Cell 49:191-202

Herrera AH, Olson MOJ (1986) Association of protein C23 with rapidly labeled nucleolar RNA. Biochem J $25: 6258-6264$

Hügle B, Hazan R, Scheer U, Franke WW (1985a) Localization of ribosomal protein $\mathrm{S} 1$ in the granular component of the interphase nucleolus and its distribution during mitosis. J Cell Biol 100:873-886

Hügle B, Scheer U, Franke WW (1985b) Ribocharin: a nuclear $M_{r} 40000$ protein specific to precursor particles of the large ribosomal subunit. Cell $41: 615-627$

Kalden JR, Feltkamp TEW (eds) (1982) Antibodies to nuclear antigens. Immunological specificity and clinical implications. Exerpta Medica, Amsterdam-Oxford-Princeton

Kistler J, Duncombe Y, Laemmli UK (1984) Mapping nucleolar proteins with monoclonal antibodies. J Cell Biol 99:1981-1988

Krohne G, Stick R, Kleinschmidt JA, Moll R, Franke WW, Hausen P (1982) Immunological localization of a major karyoskeletal protein in nucleoli of oocytes and somatic cells of Xenopus laevis. J Cell Biol 94:749-754

Lacoste-Royal G, Simard R (1984) Distribution of U3 snRNA in the nucleolus of CHO cells. Biol Cell 52:191-194

Lapeyre B, Bourbon H, Amalric F (1987) Nucleolin, the major nucleolar protein of growing eukaryotic cells: an unusual protein structure revealed by the nucleotide sequence. Proc Natl Acad Sci USA 84:1472-1476

Lischwe MA, Richards RL, Busch RK, Busch H (1981) Localization of phosphoprotein $\mathrm{C} 23$ to nucleolar structures and the nucleolar organizing regions. Exp Cell Res 136:101109

Lischwe MA, Ochs RL, Reddy R, Cook RG, Yeoman LC, Tan EM, Reichlin M, Busch H (1985) Purification and partial characterization of a nucleolar scleroderma antigen $(\mathrm{Mr}=34000 ; \mathrm{pI}, 8.5)$ rich in $\mathrm{N}^{\mathrm{G}}, \mathrm{N}^{\mathrm{G}}$-dimethylarginine. $\mathrm{J}$ Biol Chem 260:14304-14310

Lührmann R, Appel B, Bringmann P, Rinke J, Reuter R, Rothe $\mathrm{S}$ (1982) Isolation and characterization of rabbit antim2'2'7G antibodies. Nucl Acids Res 10:7103-7113

Maniatis T, Reed R (1987) The role of small nuclear ribonucleoprotein particles in pre-mRNA splicing. Nature $325: 673-678$

Mathews MB, Bernstein RM (1983) Myositis autoantibody inhibits histidyl-tRNA synthetase: a model for autoimmunity. Nature 304:177-179

Mathews MB, Reichlin M, Hughes GRV, Bernstein RM (1984) Antithreonyl-tRNA synthetase, a second myositis related autoantibody. J Exp Med 160:420-434

Maul GG, French BT, van Venrooij WJ, Jiminez SA (1986) Topoisomerase I identified by scleroderma-70 antisera, enrichment of topoisomerase I at the centromere in mouse mitotic cells before anaphase. Proc Natl Acad Sci USA $83: 5145-5149$

Morris GE, Man N, Head LP (1985) Monoclonal antibodies against a nucleolar protein from differentiating chick muscles cells. J Cell Sci 76:105-113

Ochs RL, Lischwe MA, O'Leary P, Busch H (1983) Localization of nucleolar phosphoproteins B23 and C23 during mitosis. Exp Cell Res 146:139-149

Ochs RL, Lischwe MA, Spohn WH, Busch H (1985) Fibrillarin: a new protein of the nucleolus identified by autoimmune sera. Biol Cell 54:123-134

Olson MOJ, Guetzow K, Busch H (1981) Localization of 
phosphoprotein $\mathrm{C} 23$ in nucleoli by immunological methods. Exp Cell Res 135:259-265

Padgett RA, Mount SM, Steitz JA, Sharp PA (1983) Splicing of messenger RNA precursors is inhibited by antisera to small nuclear ribonucleoprotein. Cell 35:101-107

Parker KA, Steitz JA (1987) Structural analyses of the human U3 ribonucleoprotein particle reveal a conserved sequence available for base-pairing with pre-rRNA. Mol Cell Biol 7:2899-2913

Pinnas JL, Northway JD, Tan EM (1973) Antinucleolar antibodies in human sera. J Immunol 111:996-1004

Prestayko AW, Tonato M, Busch H (1970) Low molecular weight RNA associated with $28 \mathrm{~S}$ nucleolar RNA. J Mol Biol 47:505-515

Reddy R, Tan EM, Henning D, Nogha K, Busch H (1983) Detection of nucleolar 7-2 ribonucleoprotein and a cytoplasmic 8-2 ribonucleoprotein with autoantibodies from patients with scleroderma. J Biol Chem 258:1383-1386

Reichlin M, Maddison PJ, Targoff I, Bunch T, Arnett F, Sharp G, Treadwell E, Tan EM (1984) Antibodies to a nuclear/ nucleolar antigen in patients with polymyositis overlap syndromes. J Clin Immunol 4:40

Reimer G, Huschka U, Keller J, Kammerer R, Hornstein OP (1983) Immunofluorescence studies in progressive systemic sclerosis (scleroderma) and mixed connective tissue disease. Br J Dermatol 109:27-36

Reimer G, Scheer U, Peters J-M, Tan EM (1986) Immunolocalization and partial characterization of a nucleolar autoantigen (PM-Scl) associated with polymyositis/scleroderma overlap syndromes. J Immunol 137:3802-3808

Reimer G, Rose KM, Scheer U, Tan EM (1987a) Autoantibody to RNA polymerase I in scleroderma sera. J Clin Invest 79:65-72

Reimer G, Pollard KM, Penning CA, Ochs RL, Lischwe MA, Busch H, Tan EM (1987b) Monoclonal autoantibody from NZB/NZW F1 mouse and some human scleroderma sera target at $\mathrm{M}_{\mathrm{r}} 34000$ nucleolar protein of the U3-ribonucleoprotein particle. Arthritis Rheum 30:793-800

Reimer G, Steen VD, Penning CA, Medsger TA, Tan EM (1987c) Correlates between autoantibodies to nucleolar antigens and clinical features in patients with systemic sclerosis. Arthritis Rheum (in press)

Reimer G, Scheer U, Tan EM (1987d) Immunolocalization of 7-2 ribonucleoprotein in the granular component of the nucleolus. Exp Cell Res (in press)

Ritchie RF (1969) Nucleolar structure by immunologic techniques. Cancer Res 29:267-269

Ritchie RF (1970) Antinucleolar antibodies: their frequency and diagnostic association. N Engl J Med 282:1174-1178

Ringertz NR, Ege T, Carlsson S-A (1973) Nucleolus specific antigens in human fibroblast and hybrid cells studied with patient autoantibodies. In: Kulonen E, Pikarainen QJ (eds) Biology of the fibroblast. Academic Press, New York, pp 189-194

Rose KM, Stetler DA, Jacob ST (1981) Protein kinase activity of RNA polymerase I purified from rat hepatoma: probable function of $M_{r} 42000$ and 46000 polypeptides. Proc Natl Acad Sci USA 78:2833-2837

Rose KM, Stetler DA, Jacob ST (1983) RNA polymerases from higher eukaryotes. In: Jacob ST (ed) Enzymes of nucleic acid synthesis and modification. CRC Press, Inc, Boca Raton, Florida, 43-74

Sapp M, Knippers R, Richter R (1986) DNA binding properties of a $110 \mathrm{kDa}$ nucleolar protein. Nucl Acid Res $14: 6803-6820$

Scheer U, Hügle B, Hazan R, Rose KM (1984) Drug-induced dispersal of transcribed rRNA genes and transcriptional products: immunolocalization and silver staining of different nucleolar components in rat cells treated with 5,6-dichloro- $\beta$-D-ribofuranosylbenzimidazole. J Cell Biol 99:672679

Scheer U, Rose KM (1984) Localization of RNA polymerase I in interphase cells and mitotic chromosomes by light and electron microscopic immunocytochemistry. Proc Natl Acad Sci USA 81:1431-1435

Scheer U, Messner K, Hazan R, Raska I, Hansmann P, Falk H, Spiess E, Franke WW (1987) High sensitivity immunolocalization of double and single-stranded DNA by a monoclonal antibody. Eur J Cell Biol 43:358-371

Scheer U, Raska I (1987) Immunocytochemical localization of RNA polymerase I in the fibrillar centers of nucleoli. Chromosomes Today 9:284-294

Schmidt-Zachmann MS, Hügle B, Scheer U, Franke WW (1984) Identification and localization of a novel nucleolar protein of high molecular weight by a monoclonal antibody. Exp Cell Res 153:327-346

Schmidt-Zachmann MS, Hügle-Dörr B, Franke WW (1987) A constitutive nucleolar protein identified as a member of the nucleoplasmin family. EMBO J 6:1881-1890

Seelig HP (1983) Antikörper gegen Zellkernantigene. Gustav Fischer Verlag, Stuttgart, New York

Shero JH, Bordwell B, Rothfield NF, Earnshaw WC (1986) High titers of autoantibodies to topoisomerase I (Scl-70) in sera from scleroderma patients. Science 231:737-740

Spector DL, Ochs RL, Busch H (1984) Silver staining, immunofluorescence, and immunelectron microscopic localization of nucleolar phosphoproteins B23 and C23. Chromosoma (Berl) 90:139-148

Stefano J (1984) Purified lupus antigen La recognizes an oligouridylate stretch common to the 3 termini of RNA polymerase III transcripts. Cell 36:145-154

Steitz JA, Wolin SL, Rinke J, Petterson I, Mount SM, Lerner EA, Hinterberger M, Gottlieb E (1983) Small ribonucleoproteins from eukaryotes: structures and roles in RNA biogenesis. Cold Spring Harbor Symp Quant Biol 47:893-900

Suh D, Busch H, Reddy R (1986) Isolation and characterization of a human U3 small nucleolar gene. Biochem Res Comm 137:1133-1140

Tague BW, Gerbi SA (1984) Processing of the large rRNA precursor: Two proposed categories of RNA-RNA interactions in eukaryotes. J Mol Evol 20:362-367

Tan EM, Rodnan GP, Garcia I, Moroi Y, Fritzler MJ, Peebles C (1980) Diversity of antinuclear antibodies in progressive systemic sclerosis. Anti-centromere antibody and its relationship to CREST syndrome. Arthritis Rheum 23:617-625

Tan EM (1982) Autoantibodies to nuclear antigens (ANA): their immunobiology and medicine. Adv Immunol 33: $167-240$

Thiry M, Lepoint A, Goessens G (1985) Re-evaluation of the site of transcription in Ehrlich tumor cell nucleoli. Biol Cell 54: $57-64$

Tokuyasu KT (1980) Immunocytochemistry on ultrathin frozen sections. Histochem J 12:381-403

Vaughan MA (1987) An autoimmune antibody from scleroderma patients recognize a component of the plant cell nucleolus. Histochem J 86:533-535

Wandelt C, Grummt I (1983) Formation of stable preinitiation complexes is a prerequisite for ribosomal DNA transcription in vitro. Nucl Acids Res 11:3795-3809

Zieve G, Penman S (1976) Small RNA species of the HeLa cell: metabolism and subcellular localization. Cell 8:19-31

Received September 7 / Accepted September 14, 1987 